\title{
Development and Evaluation of Physicochemical and Nutritional Properties of Protein Enriched Fortified Pulses Pasta
}

\author{
Devendra Kumar Bhatt ${ }^{1}$, Ashish Kumar Jatav ${ }^{* 1}$, Shradha Kiledar ${ }^{1}$, \\ Amit Kumar Srivastava ${ }^{2}$ \\ ${ }^{I}$ Department of Food Science and Technology, Bundelkhand University Jhansi, Uttar Pradesh, India \\ ${ }^{2}$ Department of Pharmacology, Sapience Bio-analytical Research Lab, Bhopal, Madhya Pradesh, India
}

\begin{abstract}
Pasta is a popular, nutritious and low glycaemic food having global appeal as nutrition supplement. Fortifications of pasta with a variety of proteins increase the nutritional significance of pasta and improve the health condition of the immense majority of health conscious peoples. In present study we developed five samples (C, C1, C2, C3 and C4) of pasta using refined wheat flour and different proportions of pulses (chickpea flour (Cicer arietinum), red lentil flour (Lens culinaris), white lentil flour (Vigna mungo), green gram flour (Vigna radiata) and soy flour (Glycine max). Sample $C$ was prepared as control containing only refined wheat flour (100\%), while sample C1 (refined wheat flour 90\% and pulses 10\%), C2 (refined wheat flour $80 \%$ and pulses 20\%), C3 (refined wheat flour 70\% and pulses 30\%) and C4 (refined wheat flour 60\% and pulses 40\%) were prepared by changing the concentration of refined wheat flour and different pulses. All the five samples were evaluated for the physicochemical properties (moisture content, ash value and texture analysis) nutritional properties (carbohydrate, protein, fiber and fat), cooking time and sensory qualities. A Pulses fortified pasta product was successfully produced and it was observed as the concentration of pulses was increased the cooking time also increased. On the basis of physicochemical \& nutritional properties cooking time and sensory qualities, pasta containing refined wheat flour (70\%) and pulses (30\%) resulted in better quality having more nutritional elements and highest overall acceptability.
\end{abstract}

Keywords: Pasta, fortification, protein supplementation, nutrition, health conscious peoples.

\section{Introduction}

Pasta is a nutritionally, palatable and low glycaemic food of traditional Italian cuisine. Pastas may be divided into two broad categories, dried pasta (Pasta secca) and fresh pasta (Pasta fresca). Traditionally pasta is made from unleavened dough of durum wheat semolina and formed into sheets or various shapes, then cooked and served in any number of dishes (Petitot et al. 2009). Although pasta prepared from this process has the desired texture and cooking quality but deficient in lysine and threonine imparting low biological value for the product (Stephenson 1983).

Pasta products are fetching great attention in modern phase of civilization because of their unique properties towards health, taste and convenient for carrying and preparation (Cubadda 1994). Pastas, in a broad spectrum, are considered to encompass low glycemic indices and, produce low blood glucose and insulin responses (Jenkins et al. 1983; Granfeldt et al. 1991). About 12.43 million tons of pasta is produced worldwide with an estimate of 100,000 tons of production from India (Anon 2008). Among cereals, wheat is generally considered appropriate for pasta production because their unique properties of proteins (interaction between themselves and with lipids, to produce a specific lipoprotein complex, gluten when flour and water are mixed collectively.

Pasta preparation with legumes, vegetables and natural herbs, is thought to be an inclusive, delicious and healthy food. This provides an opportunity for the use of non-traditional raw materials to increase the nutritional quality of pasta (Del Nobile et al. 2008). Among these non-traditional raw materials, legumes represent an interesting source of proteins, fibres, vitamins and minerals. Legume proteins are relatively low in sulphur-containing amino acids, methionine, cysteine and tryptophan, but high in lysine. Consequently, legumes and cereals are nutritionally complementary (Duranti 2006).

Pasta has a global appeal and good opportunities as a nutrition supplement for health conscious peoples. The addition of a growing level of proteins in pasta improves the health condition of the immense majority of health conscious peoples. Fortification of pasta with a variety of protein sources such as legume flours, soy proteins, and gluten meal has been attempted by several researchers, with a vision to increase the nutritional significance of pasta (Sadehi and Bhagya 2008; Petitot et al. 2010). The prospect of using pulses for pasta production has also been explored by different researchers (Limroongreungrat and Huang 2007).

A number of studies have been carried out for acceptable quality and good acceptance of food products made from cereal and legume flours supplemented with soya flour (Singh and Chauhan 1996; Marques et al. 2000). Chickpea and wheat flour supplemented pasta is reported for their improved protein and fibre contents 
having better acceptability as well as a dietetic alternative for people with low calorie requirements (Osorio et al. 2008; Kim 1998; Nielsen and Summer 1980). Petiot et al. investigated the impact of legume flour addition on pasta structure and the inherent consequences on the in vitro digestibility of starch. Kaur et al. produced pasta enriched with different plant proteins.

The five pulses Chickpea flour (Cicer arietinum), Red lentil flour (Lens culinaris), White lentil flour (Vigna mungo), Green gram flour (Vigna radiata), Soy flour (Glycine max) chosen for the proposed study have been reported to have health promoting functional ingredients. Keeping in view the nutritive aspects of the plant proteins aim of the present study, was to preparation of protein enriched fortified pasta with pulses having slow digestibility and high protein content and to improve the nutritional, cooking and sensory qualities of the pasta.

\subsection{Procurement of raw materials and other materials:}

\section{Material and Methods}

Refined wheat flour (Triticum aestivum) and pulses such as chickpea flour (Cicer arietinum), Red lentil flour (Lens culinaris), White lentil flour (Vigna mungo), Green gram flour (Vigna radiata), Soy flour (Glycine max) were procured from an authorized dealer of Jhansi, Uttar Pradesh, India.

\subsection{Evaluation of physicochemical and chemical composition of raw materials:}

Physicochemical (moisture content, ash value) and chemical composition (carbohydrate, protein, fiber, fat) of raw materials were evaluated according to standard internationally approved methods (2000) described by Association of Analytical Chemists (AOAC) for the assessment of quality of raw materials. Moisture content was evaluated as per AOAC-925.10 method; ash value was evaluated as per AOAC-923.03 method; protein content was determined as per (IS:7219:1973) Kjeldhal method, final protein content was obtained by using the conversion factor of 6.25; Dietary fibre was measured gravimetrically as per IS:11062 and AOAC-991.43; fat content was determined by titrimetry as per AOAC 939.05.

\subsection{Sample preparation:}

Five samples (C, C1, C2, C3 and C4) were prepared by using refined wheat flour and different proportions of pulses (Chickpea flour, Red lentil flour, White lentil flour, Green gram flour, Soy flour). Sample $\mathrm{C}$ was prepared as control containing only refined wheat flour $(100 \%)$, while sample C1 (refined wheat flour $90 \%$ and pulses 10\%), C2 (refined wheat flour $80 \%$ and pulses $20 \%$ ), C3 (refined wheat flour $70 \%$ and pulses $30 \%$ ) and $\mathrm{C} 4$ (refined wheat flour $60 \%$ and pulses $40 \%$ ) were prepared by changing the concentration of refined wheat flour and different pulses. All the samples were passed separately through sieve no. 10 thrice to improve mixing. Prepared samples were stored in air tight glass containers in cool and dry place for further study. Proximate composition and concentration of different raw materials is shown in table 1.

Table 1. Composition of different samples prepared with refined wheat flour and pulses

\begin{tabular}{|c|c|c|c|c|c|c|}
\hline \multirow{2}{*}{\multicolumn{2}{|c|}{ Ingredient's }} & \multirow{2}{*}{$\begin{array}{l}\text { Control } \\
\mathrm{C}\end{array}$} & \multicolumn{4}{|c|}{ Blends } \\
\hline & & & $\mathrm{C} 1$ & $\mathrm{C} 2$ & $\mathrm{C} 3$ & $\mathrm{C} 4$ \\
\hline \multicolumn{2}{|c|}{ Refined Wheat flour $(\mathrm{g})$} & 1000 & 900 & 800 & 700 & 600 \\
\hline \multirow{5}{*}{ Pulses (g) } & Chickpea Flour & - & 20 & 40 & 60 & 80 \\
\hline & Red Lentil Flour & - & 20 & 40 & 60 & 80 \\
\hline & White Lentil Flour & - & 20 & 40 & 60 & 80 \\
\hline & Green Gram Flour & - & 20 & 40 & 60 & 80 \\
\hline & Soy Flour & - & 20 & 40 & 60 & 80 \\
\hline
\end{tabular}

\subsection{Pasta Preparation:}

Refined wheat flour and pulses (chickpea flour, red lentil flour, white lentil flour,green gram flour, soy flour) samples at different level ranged were prepared in the ratio of 100:00; 90:10; 80:20; 70:30; 60:40 respectively. In each case, an accurately weighed amount of $1000 \mathrm{~g}$ of the respective sample was taken for the formulation. Sample was mixed with optimum amount of water in the mixing chamber of pasta extruder (Le Monferrina Masoero Arturo and C.S.N.C., Italy) for 10 minute to distribute the water uniformly throughout the flour. The moist flour aggregate was extruded through pasta extruder fitted with an adjustable die. The speed of the revolving sharp blade cutter in front of the die was adjusted so that the length of the pasta finished at $2 \mathrm{~cm}$ for each sample. Drying of final pasta samples were carried out in hot air oven at $45-50^{\circ} \mathrm{C}$ for $4-5 \mathrm{~h}$. The main objective of the drying was to reduce the moisture content of the samples below to about 8-10\%. Final dried products of various samples were packed in high density polyethylene (HDPE) bags for subsequent analysis.

The resultant dried products were then used for further study such as cooking time, chemical composition, texture and sensory analysis. 


\subsubsection{Physicochemical and nutritional composition of prepared pasta samples:}

Physicochemical (moisture content, ash value) and nutritional composition (carbohydrate, protein, fiber, fat) of prepared pasta samples were analyzed according to standard internationally approved methods (2000) described by the Association of Analytical Chemists (AOAC).

\subsubsection{Cooking quality of prepared pasta samples:}

The cooking quality of samples was determined by the minimum cooking time.

\subsubsection{Texture analysis of prepared pasta samples:}

The texture analysis was carried out with the help of stable micro system texture analysis TA-XT2i. It was used in cutting mode to record to require force to break pasta samples. The pasta sample was placed on the plate transversely over a metal sheet support and operated in the compression mode with the help of a probe. The probe distance was fixed to $3 \mathrm{~mm}$ to complete a test.

\subsubsection{Sensory evaluation of prepared pasta samples:}

The sensory evaluation of cooked pasta samples was carried out in order to determine the overall acceptability of the fortified pulses pasta. Each pasta samples were cooked separately in a stainless steel pan. In each case, $50 \mathrm{~g}$ pasta sample was taken and cooked in $500 \mathrm{ml}$ of water. The cooking temperature was maintained at $98-100^{\circ} \mathrm{C}$ throughout the cooking process. The cooking period began as soon as the pasta was added into the boiling water and was cooked for the time already determined. Cooked pasta was then drained, cooled to room temperature and used for sensory evaluation. Semi trained judges $(\mathrm{n}=10)$ were given approximately $20 \mathrm{~g}$ each of the five cooked samples. Each of the samples was randomly numbered using a three-digit code. Pasta was evaluated for overall acceptability (color, texture, aroma, and taste). Judges were asked to indicate their preference on a 9 -point hedonic scale with the degree of liking: $1=$ extremely dislike to $9=$ extremely like.

\subsection{Statistical analysis:}

Results are represented as Mean $\pm \mathrm{SD}$ (standard deviation) $\mathrm{n}=3$; Data were analyzed by one-way ANOVA (analysis of variance) by Duncan's new multiple range test (MRT) using GraphPad 5 software. Means in each column and differences between groups followed by the same letters are considered to be statistically not significantly different at $\mathrm{P}>0.05$.

\section{Result And Discussion}

\subsection{Evaluation of physicochemical and chemical composition of raw materials}

Physicochemical and chemical composition of raw materials were evaluated according to standard internationally approved methods (2000) described by the Association of Analytical Chemists (AOAC) for the assessment of physicochemical and chemical quality of raw materials. Results are shown in Table 2.

Table 2. Physicochemical and chemical composition of raw materials

\begin{tabular}{|l|l|l|l|l|l|l|l|}
\hline $\begin{array}{l}\text { Raw } \\
\text { materials }\end{array}$ & $\begin{array}{l}\text { Moisture } \\
\text { content }(\boldsymbol{\%})\end{array}$ & Ash value $\mathbf{( \% )}$ & $\begin{array}{l}\text { Carbohydrate } \\
(\boldsymbol{\%})\end{array}$ & Protein (\%) & Sugar (\%) & Fiber (\%) & Fat (\%) \\
\hline $\begin{array}{l}\text { Refined } \\
\text { Wheat Flour }\end{array}$ & $9.71 \pm 0.15$ & $3.65 \pm 0.03$ & $74.67 \pm 0.02$ & $10.70 \pm 0.12$ & - & $0.50 \pm 0.14$ & $1.12 \pm 0.08$ \\
\hline $\begin{array}{l}\text { Chickpea } \\
\text { Flour }\end{array}$ & $7.18 \pm 0.02$ & $3.42 \pm 0.09$ & $60.45 \pm 0.04$ & $22.48 \pm 0.06$ & $8.62 \pm 0.03$ & $22.56 \pm 0.09$ & $2.38 \pm 0.02$ \\
\hline $\begin{array}{l}\text { Red Lentil } \\
\text { Flour }\end{array}$ & $5.26 \pm 0.11$ & $2.78 \pm 0.11$ & $60.81 \pm 0.03$ & $26.43 \pm 0.02$ & $2.28 \pm 0.07$ & $31.54 \pm 0.03$ & $1.25 \pm 0.17$ \\
\hline $\begin{array}{l}\text { White Lentil } \\
\text { Flour }\end{array}$ & $7.89 \pm 0.04$ & $3.09 \pm 0.08$ & $59.32 \pm 0.11$ & $25.12 \pm 0.08$ & - & $18.63 \pm 0.11$ & $1.6 \pm 0.11$ \\
\hline Soy Flour & $7.38 \pm 0.06$ & $2.91 \pm 0.04$ & $30.16 \pm 0.10$ & $36.49 \pm 0.06$ & $7.33 \pm 0.12$ & $9.3 \pm 0.03$ & $19.94 \pm 0.12$ \\
\hline $\begin{array}{l}\text { Green Gram } \\
\text { Flour }\end{array}$ & $6.44 \pm 0.03$ & $2.11 \pm 0.13$ & $62.62 \pm 0.03$ & $23.86 \pm 0.11$ & $6.60 \pm 0.05$ & $16.30 \pm 0.07$ & $1.15 \pm 0.06$ \\
\hline
\end{tabular}

Note: All values are represented as Mean \pm SD (standard deviation) $n=3$; data were analyzed by one-way ANOVA (Analysis of variance) using GraphPad Prism 5 software.

\subsection{Nutritional composition of prepared pasta samples:}

Nutritional characteristics of final products were analyzed according to standard internationally approved methods (2000) described by the Association of Analytical Chemists (AOAC).

Fortification of pasta with different pulses significantly increases the protein, fat, sugar and fiber content of final product, while carbohydrate content of prepared pulse pasta decreased in comparison to control pasta. The results are shown in table 3. 
Table 3. Physicochemical and nutritional composition, of prepared pasta samples

\begin{tabular}{|l|l|l|l|l|l|l|}
\hline Sample & $\begin{array}{l}\text { Moisture content } \\
(\boldsymbol{\%})\end{array}$ & Ash value (\%) & Carbohydrate (\%) & Protein (\%) & Fiber (\%) & Fat (\%) \\
\hline C & $7.78 \pm 0.32^{\mathrm{a}}$ & $1.09 \pm 0.05^{\mathrm{a}}$ & $74.67 \pm 0.67^{\mathrm{a}}$ & $10.70 \pm 0.71^{\mathrm{a}}$ & $0.50 \pm 1.23^{\mathrm{ac}}$ & $1.12 \pm 0.63^{\mathrm{a}}$ \\
\hline C1 & $8.35 \pm 0.46^{\mathrm{b}}$ & $1.18 \pm 0.03^{\mathrm{b}}$ & $72.67 \pm 0.44^{\mathrm{c}}$ & $12.50 \pm 0.47^{\mathrm{b}}$ & $2.42 \pm 0.13^{\mathrm{b}}$ & $1.53 \pm 0.09^{\mathrm{b}}$ \\
\hline C2 & $8.69 \pm 0.38^{\mathrm{b}}$ & $1.45 \pm 0.08^{\mathrm{c}}$ & $70.67 \pm 0.49^{\mathrm{c}}$ & $14.29 \pm 0.66^{\mathrm{c}}$ & $4.33 \pm 0.17^{\mathrm{bc}}$ & $1.95 \pm 0.12^{\mathrm{b}}$ \\
\hline C3 & $8.21 \pm 0.23^{\mathrm{b}}$ & $1.77 \pm 0.02^{\mathrm{b}}$ & $68.67 \pm 0.28^{\mathrm{b}}$ & $16.09 \pm 0.38^{\mathrm{b}}$ & $6.25 \pm 0.11^{\mathrm{b}}$ & $2.36 \pm 0.06^{\mathrm{b}}$ \\
\hline C4 & $8.55 \pm 0.29^{\mathrm{c}}$ & $1.91 \pm 0.04^{\mathrm{b}}$ & $66.67 \pm 0.32^{\mathrm{b}}$ & $17.90 \pm 0.39^{\mathrm{c}}$ & $8.17 \pm 0.14^{\mathrm{b}}$ & $2.78 \pm 0.14^{\mathrm{ac}}$ \\
\hline
\end{tabular}

Note: All values are represented as Mean \pm SD (Standard deviation) $n=3$; mean in each column and differences between groups followed by the same letters are considered to be statistically not significantly different at $\mathrm{P}>0.05$.

\subsection{Cooking quality of prepared pasta samples}

Cooking time of pasta sample was significantly increased as compare to the control sample, in each case $50 \mathrm{gm}$ of each sample was taken and cooked separately for the evaluation of cooking time. The results are shown in table 4 . We observed that cooking time of the pasta increased linearly with protein content.

Table 4. Cooking time of prepared pasta samples

\begin{tabular}{|l|l|}
\hline Sample & Cooking time (min) \\
\hline C & $7.6 \pm 0.25^{\mathrm{a}}$ \\
\hline C1 & $8.5 \pm 0.15^{\mathrm{c}}$ \\
\hline C2 & $8.9 \pm 0.12^{\mathrm{c}}$ \\
\hline C 3 & $9.3 \pm 0.08^{\mathrm{b}}$ \\
\hline C4 & $9.6 \pm 0.10^{\mathrm{c}}$ \\
\hline
\end{tabular}

Note: All values are represented as Mean \pm SD (standard deviation) $n=3$; mean in each column and differences between groups followed by the same letters are considered to be statistically not significantly different at $\mathrm{P}>0.05$.

\subsection{Texture analysis of prepared pasta samples}

The texture analysis was carried out with the help of stable micro system texture analysis TA-XT2i. It was used in cutting mode to record to required force to break pasta samples. The pasta sample was placed on the plate transversely over a metal sheet support and operated in the compression mode with the help of a probe. The probe distance was fixed to $3 \mathrm{~mm}$ to complete a test. It was found that the cutting force of the pasta product was increased. The results are shown in table 5 and figure 1.

Table 5. Texture analysis of prepared pasta samples

\begin{tabular}{|l|l|}
\hline Sample & Pulses pasta cutting force \\
\hline $\mathrm{C}$ & $2355.83 \pm 0.09^{\mathrm{a}}$ \\
\hline $\mathrm{C} 1$ & $2572.56 \pm 0.05^{\mathrm{b}}$ \\
\hline $\mathrm{C} 2$ & $2389.80 \pm 0.06^{\mathrm{ab}}$ \\
\hline $\mathrm{C} 3$ & $3106.23 \pm 0.02^{\mathrm{b}}$ \\
\hline $\mathrm{C} 4$ & $3232.80 \pm 0.03^{\mathrm{b}}$ \\
\hline
\end{tabular}

Note: All values are represented as Mean \pm SD (standard deviation) $n=3$; mean in each column and differences between groups followed by the same letters are considered to be statistically not significantly different at $\mathrm{P}>0.05$.

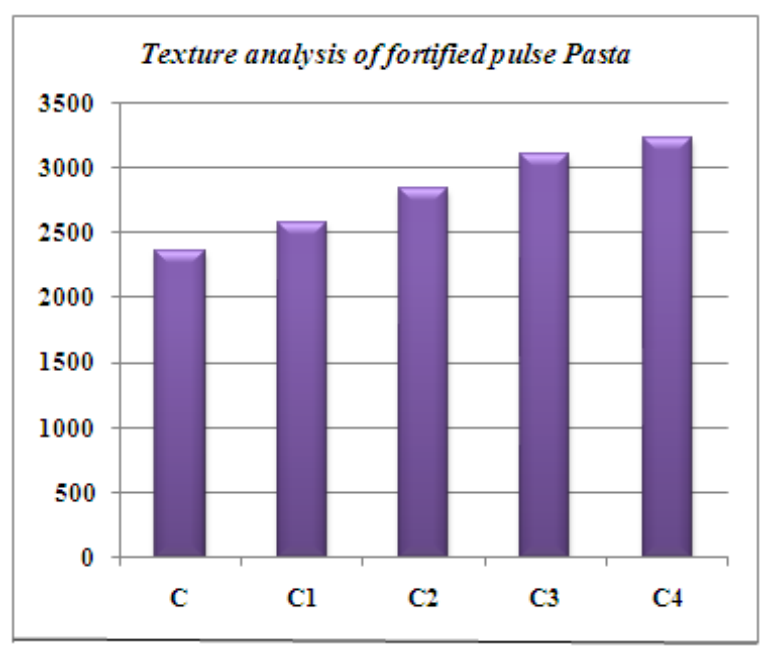

Fig. 1. Texture analysis of prepared pasta samples 
Note: C-control sample, $\mathrm{C} 1-10 \%$ pulses, C2-20\% pulses, C3- 30\% pulses, C4- 40\% pulses

\subsection{Sensory characteristics of prepared pasta samples}

Sensory evaluation was carried out as per 9 point hedonic scale. Among the four fortified samples, the third sample (C3) had the highest overall acceptability, in comparison to the control. Physical analysis of fortified pulses pasta samples revealed that increasing the level of pulses flour resulted in pasta with a darker color and higher cooking loss than pasta at lower levels of pulses flour.

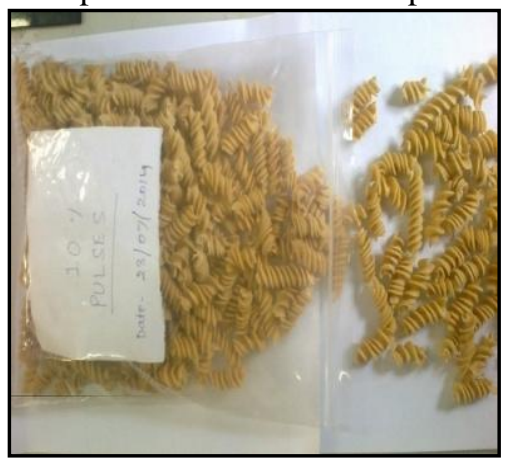

Fig. 2. Fortified pasta sample C1

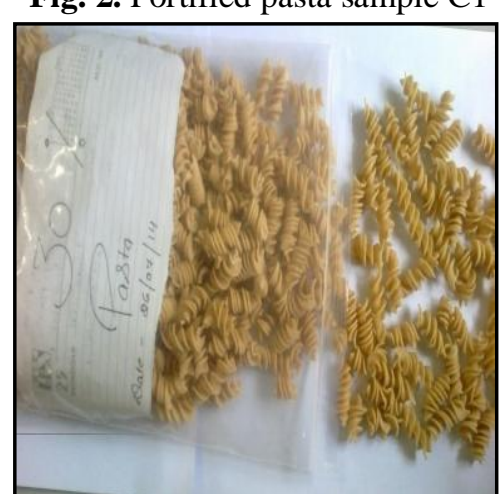

Fig. 4. Fortified pasta sample C3

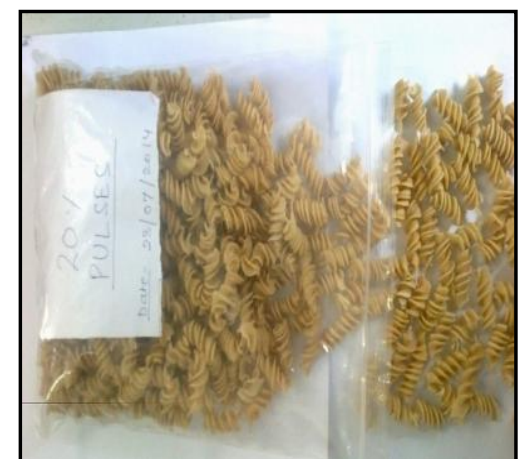

Fig. 3. Fortified pasta sample $\mathrm{C} 2$

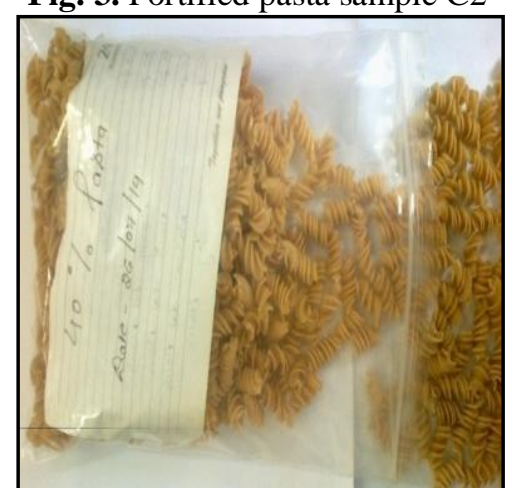

Fig. 5. Fortified pasta sample C4

Table 6. Sensory scores of prepared pasta samples

\begin{tabular}{|l|l|l|l|l|l|}
\hline \multirow{2}{*}{ Sample } & Sensory Parameters & \multicolumn{2}{l|}{$\begin{array}{l}\text { Overall } \\
\text { Acceptability }\end{array}$} \\
\cline { 2 - 6 } & Color & Texture & Aroma & Taste & $10.96 \pm 0.91^{\mathrm{b}}$ \\
\hline C & $9.11 \pm 1.13^{\mathrm{b}}$ & $10.23 \pm 0.82^{\mathrm{b}}$ & $9.89 \pm 1.22^{\mathrm{b}}$ & $11.56 \pm 0.85^{\mathrm{ab}}$ & $7.25 \pm 078^{\mathrm{b}}$ \\
\hline C1 & $7.0 \pm 0.81^{\mathrm{ab}}$ & $6.5 \pm 0.63^{\mathrm{b}}$ & $6.5 \pm 0.74^{\mathrm{b}}$ & $7.0 \pm 0.69^{\mathrm{ab}}$ & $7.75 \pm 081^{\mathrm{b}}$ \\
\hline C2 & $7.5 \pm 0.52^{\mathrm{a}}$ & $7.0 \pm 0.42^{\mathrm{b}}$ & $7.5 \pm 0.88^{\mathrm{b}}$ & $8.0 \pm 0.52^{\mathrm{a}}$ & $8.50 \pm 0.52^{\mathrm{a}}$ \\
\hline C3 & $8.5 \pm 0.31^{\mathrm{a}}$ & $8.0 \pm 0.22^{\mathrm{a}}$ & $8.5 \pm 0.64^{\mathrm{a}}$ & $8.5 \pm 0.44^{\mathrm{a}}$ & $8.00 \pm 0.66^{\mathrm{b}}$ \\
\hline C4 & $8.0 \pm 0.76^{\mathrm{b}}$ & $7.5 \pm 0.37^{\mathrm{a}}$ & $8.0 \pm 0.71^{\mathrm{b}}$ & $7.5 \pm 0.49^{\mathrm{ab}}$ & ${ }^{\mathrm{b}}$ \\
\hline
\end{tabular}

Note: All values are represented as Mean \pm SD (standard deviation) $n=3$; mean in each column and differences between groups followed by the same letters are considered to be statistically not significantly different at $\mathrm{P}>0.05$.

\section{Conclusion}

Chickpea flour, red lentil flour, white lentil flour, green gram flour, soy flour increased the protein, fibre and sugar content of the pasta keeping the fat at optimum level. Fortification increased the cooking time, and stiffness of the samples than control. Fortified pasta was highly acceptable with respect to sensory attributes and cooking time.

On the basis of physicochemical \& nutritional properties cooking time and sensory qualities, pasta containing $70 \%$ refined wheat flour and $30 \%$ pulses (chickpea flour, red lentil flour, white lentil flour, green gram flour, soy flour) resulted in better quality having more nutritional elements and highest overall acceptability. Developed pasta can be used as a nutritious food for low income group in developing countries and for health conscious peoples.

\section{Acknowledgement}

The authors are thankful to the Bundelkhand University Jhansi Uttar Pradesh, India for providing the necessary research facilities for the successful completion of research work. 


\section{Conflict of Interest}

The authors declare that there are no conflicts of interest.

\section{References}

[1]. R. Cubadda, Nutritional value of pasta. Effects of processing conditions, Italian Journal of Food and Beverage Technology, 3, 1994, 27-33.

[2]. DJ. Jenkins, TM. Wolever, AL. Jenkins, R. Lee, GS. Wong, and R. Josse, Glycemic response to wheat products: reduced response to pasta but no effect of fiber. Diabetes Care, 6(2), 1983, 155-159.

[3]. Y. Granfeldt, I. Bjorck, and B. Hagander, On the importance of processing conditions, product thickness and egg addition for the glyceamic and hormonal responses to pasta: A comparison with bread made from pasta ingredients, European Journal of Clinical Nutrition, 45(10), 1991, 489-499.

[4]. Anon, Estimate of world pasta production, Union of Organizations of Manufacturers of Pasta Products of the European Union, 2008.

[5]. M. Petitot, J. Abecassis, and V. Micard, Structuring of Pasta Components during Processing: Impact on Starch and Protein Digestibility and Allergenicity, Trends in Food Science and Technology, 20(11-12), 2009, 521-532.

[6]. C. Stephenson, World's Best Pasta, Macaroni Journal, 65, 1983, 4-8.

[7]. MA. Sadehi, and S. Bhagya, Quality Characteristics of Pasta Enriched with Mustard Protein Isolate, Journal of Food Science, 73(5), 2008, S229-S237.

[8]. M. Petitot, L. Boyer, C. Minier, and V. Micard, Fortification of Pasta with Split Pea and Faba Bean Flours: Pasta Processing and Quality Evaluation, Food Research International, 43(2), 2010, 634-641.

[9]. K. Limroongreungrat, and YW. Huang, Pasta Products Made from Sweet Potato Fortified with Soy Protein, LWT Food Science \& Technology, 40(2), 2007, 200-206.

[10]. MA. Del Nobile, A. Baiano, A. Conte, and G. Mocci, Influence of protein content on spaghetti cooking quality, Journal of Cereal Science, 41(3), 2005, 347-356.

[11]. M. Duranti, Grain legume proteins and nutraceutical properties, Fitoterapia, 77(2), 2006, 67-82.

[12]. R. Singh and GS. Chauhan, Effect of incorporation of defatted soy flour on the quality of biscuits, Journal of Food Science and Technology, 33(4), 1996, 355-357.

[13]. M. Marques, PS. Bora, and N. Narain, Development of some high protein conventional foods based on wheat and oilseed flours, Journal of Food Science and Technology, 37(4), 2000, 394-399.

[14]. DP. Osorio, AE. Acevedo, MM. Vinalay, JB. Tovar, and LA. Bello-Perez, Pasta added with chickpea flour: Chemical composition, In vitro starch digestibility and predicted glycemic index, Ciencia y Tecnologia Alimentaria, 6(1), 2008, 6-12.

[15]. YS. Kim, Quality of wet noodles prepared with wheat flour and mushroom powder, Korean Journal of Food Science and Technology, 30, 1998, 1373-1380.

[16]. MA. Nielsen, and A. Summer, Fortification of pasta with pea flour and air classified pea protein concentrate, Cereal Chemistry 57(3), 1980, 203-206.

[17]. M. Petiot, C. Barron, and V. Micard, Impact of legume flour addition on pasta structure: consequences on its in vitro starch digestibility, Food Biophysics, 5(4), 2010, 284-299.

[18]. G. Kour, S. Sharma, and HPS. Nagi, Enrichment of pasta with different plant proteins, Journal of Food Science and Technology, 50(5), 2013, 1000-1005

[19]. Approved laboratory methods, American Association of Cereal Chemists (AACC), Minnesota, USA, 2010

[20]. Association of Analytical Chemists (AOAC), Official Methods of Analysis of AOAC International, 17th edition, W. Horwitz, editor, Maryland, USA, 2000. 